\title{
Küreselleşme ve Yaşam Beklentisi Üzerine Araştırma: Panel Regresyon Analizi
}

\section{Research on Globalization and Life Expectancy: Panel Data Regression Analysis}

\author{
Mustafa Necati ÇOBAN ${ }^{a, *}$ \\ a Dr. Öğr. Üyesi, Tokat Gaziosmanpaşa Üniversitesi, İktisadi ve İdari Bilimler Fakültesi, Tokat/Türkiye. \\ ORCID: 0000-0003-2839-4403
}

$\begin{array}{ll}\text { MAKALE BİLGİSİ } & \\ \text { Makale Geçmişi: } & \\ \text { Başvuru tarihi: 01 Ocak } 2020 & \\ \text { Düzeltme tarihi: 22 Nisan } 2020 & \\ \text { Kabul tarihi: 28 Nisan } 2020 & \\ \text { Anahtar Kelimeler: } & \\ \text { Küreselleşme } & \\ \text { Yaşam Beklentisi } & \\ \text { Panel Veri Analizi } & \end{array}$

\section{A R T I C L E IN F O}

\section{Article history:}

Received 01 January 2020

Received in revised form 22 April 2020

Accepted 28 April 2020

Keywords:
Globalization
Life Expectancy
Panel Data Analysis

ÖZ

Bu çalışmanın amacı küreselleşmenin bir sağlık ve refah göstergesi olarak doğuşta yaşam beklentisi üzerine etkilerinin Eagles Ülkeleri kapsamında saptanmasıdır. Belirtilen amaç doğrultusunda Eagles Ülkelerine ait 1990-2017 dönemini kapsayan veriler kullanılarak dengeli panel veri analizi gerçekleştirilmiştir. Küreselleşme göstergesi ve bağımsız değişken olarak KOF Küreselleşme Endeksi kullanılmıştır. Doğuşta yaşam beklentisi bağımlı değişken olup aynı zamanda çalışmaya kişi başına düşen GSYİH, kentleşme oranı ve gayrisafi sermaye oluşumu gibi açılayıcı değişkenler eklenmiştir. Çalışmada ulaşılan sonuçlar Eagles Ülkeleri'nde küreselleşmenin yaşam beklentisini olumlu etkilediği yönündedir.

\section{A B S T R A C T}

The aim of this study is to determine the effects of globalization on life expectancy at birth as an indicator of health and welfare within the Eagles Countries. For this purpose, balanced panel data analysis was performed by using the data of the Eagles Countries covering the period of 1990-2017. KOF Globalization Index was used as an indicator of globalization and as an independent variable. Life expectancy at birth is dependent variable, and explanatory variables such as GDP per capita, urbanization rate and gross capital formation were added to the study. The results of the study indicate that globalization positively affects life expectancy in Eagles Countries.

\section{Giriş}

Ülkelerin ve toplumların birbirleri ile sosyal, kültürel ve ekonomik olarak etkileşime geçmeleri sonucu ülkeler arası sınırlar kaybolmuş, küresel bir dünya yapısı ortaya çıkmıştır. Bilgi ve iletişim teknolojilerinin yaygınlaşması ile beraber insanlar sosyal ve kültürel olarak etkileşime geçmiş, küreselleşmenin getirdiği teknolojik gelişim bireylerin yaşam stillerinin değişime uğramasına yol açmıştır. İktisadi perspektiften küreselleşme kavramı incelendiğinde özellikle serbest piyasa ekonomisi anlayışı ile beraber uluslararası ticari faaliyetlerin hızlanması bilginin, teknolojinin, mal ve hizmet hareketlerinin başka ülkelere de yayılmasına olanak tanımıştır.
Küreselleşmenin gelişim süreci incelendiğinde, 80'li y1llardan bu yana dünya ekonomisinin birbiri ile entegrasyonunun sürekli arttığı gözlemlenmektedir. Bilgi ve iletişim teknolojilerinin yaygınlaşması ve azalan ulaştırma maliyetleri mesafe kavramının gittikçe azalmasına yol açmaktadır. Öte yandan ticari faaliyetler, yatırımlar, sermaye akımları ve teknoloji transferleri küreselleşme ile beraber artmaktadır (Lee ve Vivarelli, 2006: 2).

Küreselleşme, bilgiye ulaşımın maliyetinin azalması, teknoloji transferi ve sermaye akımlarının artarak daha yüksek ekonomik büyüme oranlarına ulaşılması gibi avantajlar sağlayabildiği gibi küreselleşme karşıtları tarafından çokuluslu şirketlerin aşırı güçlenmesine olanak tanındı̆̆ı ve gelirin adil dağılımına ve istihdama olumsuz

\footnotetext{
* Sorumlu yazar/Corresponding author

e-posta: necati.coban@gop.edu.tr
} 
yönde etki ettiği biçiminde eleştirilere maruz kalabilmektedir (Stallings, 2002: 8; Whalley, 2005: 18).

Doğuşta yaşam beklentisi, belirli bir yılda doğan bireyin ortalama kaç sene yaşayacağını ifade eden bir kavram olarak gösterilmekle beraber aynı zamanda ülkelerin sağlık sistemlerinin gelişmişliği ve refah seviyeleri hakkında fikir vermektedir. Doğuşta yaşam beklentisi kavramının önemli bir sağlık ve refah göstergesi olarak değerlendirildiği bilinmektedir.

Az gelişmiş ve gelişmekte olan ülkeler ile gelişmiş ülkelerde doğuşta yaşam beklentisinin farklı seviyelerde olduğu görülmektedir. Ülkelerin gelişmişlik düzeyleri arttıkça doğuşta beklenen yaşam süresi de artmaktadır. Bebek ölümlerinin ve çocuk yaştaki ölümlerin yüksek olması doğuşta yaşam beklentisini azaltmaktadır. Az gelişmiş ve gelişmekte olan ülkelerde bebek ve çocuk ölüm sayısı gelişmiş ülkelere göre fazladır (Rabbi, 2013: 480).

Küreselleşmenin doğuşta yaşam beklentisi üzerine etkili olduğu ifade edilmektedir. Toplumların ve ekonomilerin birbirine entegre olmasını ve araştırma ve geliştirme deneyimlerini paylaştığı bir kavram olarak küreselleşmenin yaşam beklentisini etkilediği birkaç kanal bulunmaktadır. Küreselleşme ile bir ülkeden diğer ülkelere mal veya hizmet transferleri artmakta ve insanlar için önem arz eden gıda maddeleri ve hayati önem taşıyan ilaçlar daha fazla nüfus için erişilebilir hale gelmektedir. Küreselleşme ile beraber hastalıklarla mücadele kapsamında önemli olan bilginin yayılması sağlanabilir ve insan hayatı için önemli olan insan haklarıyla alakalı farkındalık artırılabilir (Ali ve Audi, 2016: 183).

Küreselleşme ile beraber eğitim, sağlık turizmi ve modern sağlık teknolojisine erişim yoluyla sağlık göstergelerinde iyileşme gözlemlendiği ifade edilmektedir. Bu görüşün aksini savunan belirli bir kesim de bulunmaktadır. Bu kesime göre de ekonomik küreselleşme ile beraber sağlıksız ürünler pazarlanabilmekte, sahte ilaçlar ve alanında uzman sağlık çalışanlarının göçü yoluyla büyük sağlık tehlikeleri ile karşılaşılabildiği ve bulaşıcı hastalıkların daha kolay bulaşabildiği ifade edilmektedir (Timothy, 2018: 2).

Küreselleşmenin ülkelerde sağlık imkanlarını geliştirdiğini savunan kesim küreselleşme ile halkın sağlığına yönelik daha fazla tedbirlerin alınabildiğine ve gerekli olanakların sağlandığını belirtmektedir. Küreselleşme ile beraber daha hılı ekonomik büyüme oranları yakalanabilmekte, kişi başına düşen gelir artmakta, bireylerin yaşam standartları yükselmekte, yenilikler ve inovasyonlar dünyaya hızlıca yayılabilmektedir. Bunların dışında sağlık ve gelir düzeyi arasında karşılıklı bir ilişki olduğu unutulmamalıdır. Yüksek gelir daha daha fazla ve daha iyi sağlık hizmetlerinden yararlanabilmeyi olanaklı kılmakta iken öte yandan sağlıklı insanlar daha yüksek gelir elde edebilirler. Benzer şekilde gelir artışı, sosyal güvenlik yardımlarının artması, doktor ve kliniklere erişim ve nihai olarak küreselleşme ile beraber yaşam beklentisi artmaktadır (Rafat, Emadzadeh ve Ahmadi, 2013: 387).

Özellikle küreselleşme ile beraber hem Sahra Altı Afrika ülkelerinin hem de eski Sovyetler Birliği ve Doğu Avrupa ülkelerinin 1970 yılından bu yana hem yaşam beklentilerinin yükseldi hem de çocuk ölümlerinin azaldığı gözlemlenmektedir. Küreselleşmenin bu ülkelerdeki bu gelişmelerle ilgisinin daha yüksek gelir düzeyinin daha iyi sağlık imkanlarını teşvik ettiği fikrinden ileri geldiği belirtilmektedir (Fischer, 2003: 11). Az gelişmiş ülkelerde gelir ve sağlık değişkenleri arasındaki ilişkinin oldukça güçlü olduğu düşünülmekle beraber küreselleşmeye bağlı olarak yoksulluğun azaltılmasının sağlık göstergeleriniiyileştirdiği belirtilmektedir (Preston, 1975; Summers ve Pritchett, 1996).

Bu çalışmada Eagles Ülkelerinde küreselleşmenin doğuşta yaşam beklentisi üzerine olan etkilerinin araştırılması amaçlanmaktadır. Belirtilen amaç doğrultusunda Eagles Ülkelerinin 1990-2017 dönemine ait verileri kullanılarak dengeli panel veri analizi gerçekleştirilmiştir. Çalışmada 2. Bölümde literatür taraması yer almaktadır. 3. Bölümde çalışmada kullanılan veri seti ve yöntem tanıtılmıştır. 4. Bölümde ampirik bulgulardan bahsedilmiş, 5. Bölümde ise modele dair tahmin sonuçlarına yer verilmiştir. Nihai olarak ise sonuç bölümü yer almakta olup çalışmada elde edilen sonuçlara dair değerlendirme gerçekleştirilmiştir.

\section{Literatür Taraması}

İlgili literatür incelendiğinde sağlık göstergesi olarak doğumda yaşam beklentisinin literatürde daha az kullanıldığı gözlemlenmektedir. Yine küreselleşme ve yaşam beklentisi arasındaki ilişkiyi doğrudan araştıran çalışmaların sayısının az olduğu görülmektedir.

Bezruchka (2000), küreselleşmenin sağlık üzerine olası olumsuz etkilerinden yola çıkarak küreselleşmenin sağlık sektörü üzerine avantaj ve dezavantajlarını değerlendirmiştir. Küreselleşme ile beraber artan ticari faaliyetlerin kirliliğin artmasına yol açabileceği bunun dışında küreselleşmenin sigara ihracatını genişletebileceği ve genetiği değiştirilmiş gıdaların yaygınlaşabilmesine yol açabileceği ifade edilmekte iken diğer yandan sağlık hizmetlerinin fakir ülkelere doğru yaygınlaşabilmesi kapsamında firsatlar oluşturabileceği de belirtilmiştir.

Cornia (2001), küreselleşme ve sağlık arasındaki ilişkiye yönelik bir araştırma gerçekleştirmiştir. Piyasaların dışlayıcı olmadığı ve düzenleyici kurumların güçlü olduğu ülkelerde küreselleşmenin önemli firsatlar yaratacağı ifade edilmiştir. Çin, Kosta Rika, Asya Kaplanları ve Vietnam'daki sağlık hizmetine yönelik kazanımların küreselleşmeyle beraber küresel pazarlara ve teknolojiye yönelik artan erişimleriyle ilişkilendirilmektedir. Fakat çoğu Afrika ülkesinde, Latin Amerika ülkelerinde ve Doğu Avrupa ülkelerinde küreselleşmenin dış yatırımların eşitsiz dağılımı ve zayıf iç koşulların birleşimi ile beraber bu ülkelerde sağlık hizmeti üzerine etkisiz kaldığı ifade edilmiştir.

Diaz-Bonilla vd. (2002), gelişmekte olan ülkelerde küreselleşen sağlık hizmetlerini araştırmışlardır. Küreselleşmenin sağlık sektörü için önemli firsatlar sunmakla beraber önemli zorluklar ortaya koyduğu da ifade edilmiştir. Küreselleşme ile beraber son 40 yılda sağlık alanında önemli ilerlemeler kaydedildiği belirtilmiş fakat bu ilerlemelerin bölgeler arasında eşit olmayan bir şekilde dağıtıldığı dile getirilmiştir. Çalışma kapsamında küreselleşmenin gelişmekte olan ülkelerdeki sağlık sektörü üzerindeki olumsuz etkilerini azaltmaya ve olumlu etkilerini artırmaya yönelik birtakım politika önerilerinde bulunulmuştur. 
Deaton (2004), küreselleşme çağındaki sağlık hizmetine yönelik faaliyetlerle alakalıbir değerlendirme gerçekleştirmiştir. Küreselleşmenin ekonomik büyümeyi desteklemesi ile beraber son 50 yılda yaşam beklentisi kapsamında uluslararası düzeydeki eşitsizliklerin azaldığı vurgulanmıştır. Küreselleşmenin, zengin ülkelerden fakir ülkelere geçiş sürecinin hızlanmasının, küresel sağlı için çok daha etkili olacağı ifade edilmiştir.

Bergh ve Nilsson (2010), küreselleşme ve yaşam beklentisi arasındaki ilişkiyi araştırmışlardır. 1970-2005 dönemine ait verilerin kullanıldığı çalışmada 92 ülke panel veri analizi gerçekleştirilerek incelenmiştir. Çalışmada sonuç olarak ekonomik küreselleşmenin yaşam beklentisi üzerinde pozitif yönlü ve istatistiksel olarak anlamlı bir etkide bulunduğu tespit edilmiştir. Sonuç yalnızca düşük gelirli ülkeler kapsamında geçerlidir.

Labonte, Mohindra ve Schrecker (2011), küreselleşmenin sağlık sektörü üzerindeki artan etkilerini değerlendirmişlerdir. Küreselleşmenin ve sağlık sektörünün önündeki zorlukların tartışıldığı çalışmada ulusal hükümetlere ve özellikle zengin ülkelerin ulusal hükümetlerine tüm dış politikalarında küresel sağlığı ve bunun sosyal belirleyicilerini daha fazla dikkate almaları yönünde önerilerde bulunulmuştur.

Rafat, Emadzadeh ve Ahmadi (2013), gelişmekte olan ülkelerde ekonomik, sosyal ve siyasi küreselleşmenin sağlik üzerine olan etkilerini incelemişlerdir. Çalışmada elde edilen sonuçlar incelendiğinde ekonomik küreselleşmenin sağlık üzerinde olumsuz bir etkiye neden olduğu gözlemlenmiştir. Bunun dişında sosyal ve siyasi küreselleşmenin sağlık üzerinde pozitif ve istatistiksel olarak anlamlı bir etkiye sahip olduğu görülmektedir. Sonuç hem kadınlar hem de erkekler için aynıdır.

Monsef ve Mehrjardi (2015), yaşam beklentisinin belirleyicileri üzerine araştırma gerçekleştirmiştir. 136 ülkeye ait 2002-2010 dönemine ait verilerin kullanıldığı çalışmada panel veri analizi gerçekleştirilmiştir. Çalışmada ulaşılan sonuçlar incelendiğinde, enflasyon ve işsizliğin yaşam beklentisini olumsuz yönde etkilediği tespit edilmişken gayrisafi sermaye oluşumu ve gayri safi milli hasılanın yaşam beklentisini pozitif yönde etkilediği bulgularına ulaşılmıştır.

Welander, Lyttkens ve Nilsson (2015), gelişmekte olan ülkelerde küreselleşmenin çocuk sağlığ 1 üzerine olan etkilerini analiz etmişlerdir. 70 gelişmekte olan ülkenin 1970-2009 dönemine ait verilerinin kullanıldı̆̆ çalışmada panel veri analizi gerçekleştirilmiştir. Bulgular incelendiğinde gelişmekte olan ülkelerde küreselleşmenin bebek ölümlerini azalttığı tespit edilmiştir.Buna ek olarak demokrasi düzeyinin çocuk sağlığı düzeyi üzerinde olumlu etkide bulunduğu gözlemlenmiştir.

Ali ve Audi (2016), küreselleşme, gelir eşitsizliği ve çevresel bozulmanın yaşam beklentisi üzerine olan etkilerini incelemişlerdir. Pakistan'a ait 1980-2015 dönemine ait verilerin kullanıldığı çalışmada değişkenler arası uzun dönemli ilişkiyi analiz etme amacıyla ARDL analizi gerçekleştirilmiştir. Pakistan'da gelir eşitsizliği ve çevresel bozulmanın yaşam beklentisini olumsuz yönde etkilediğinin tespit edildiği çalışmada ayrıca küreselleşmenin Pakistan'da yaşam beklentisini pozitif yönde etkilediği bulgusuna ulaşılmıştır. Daha sonra nedensellik ilişkisinin test edildiği çalışmada tüm bağımsız değişkenlerden bağımlı değişkene doğru tek yönlü nedensellik ilişkisinin varlığı tespit edilmiştir.

Ertaş ve Kıraç (2017), küreselleşmenin ülkelerin sağlık sistemleri ve sağlı politikalarına olan etkilerini araştırmışlardır. Nitel araştırma deseni yönteminin benimsendiği çalışmada ilgili literatür taranmıştır. Çalışma neticesinde ülkelerin küreselleşmenin olumsuz etkilerinden korunmak için sağlık alanında uluslararası işbirlikleri gerçekleştirmeleri ve anlaşmalar yapmaları gerekliliği ifade edilmiştir.

Timothy (2018), ekonomik küreselleşmenin yaşam beklentisi üzerine etkisini analiz etmiştir. 1986-2016 y1lları arasındaki verilerin kullanılarak Nijerya'nın incelendiği çalışmada Johanson Eşbütünleşme Testi uygulanmıştır. Değişkenler arası uzun dönemli ilişkinin analiz edildiği çalışmada Nijerya'da ekonomik küreselleşmenin yaşam beklentisi üzerinde pozitif yönlü ve istatistiksel olarak anlamlı bir etkiye sahip olduğu gözlemlenmiştir.

\section{Veri Seti ve Yöntem}

Çalışmada EAGLEs (Yükselen ve Büyümenin Öncüsü Ekonomiler) ülkelerine ait 1990-2017 dönemine ait veriler kullanılarak panel veri analizi gerçekleştirilmiştir. Çalışmada analiz edilecek veri aralığının tespit edilmesinde seçilen tüm değişkenler kapsamında verilerin mevcut olması etkili olmuştur. Değişkenlerin tercih edilmesinde ise benzer çalışmalardan (Rafat, Emadzadeh ve Ahmadi, 2013; Monsef ve Mehrjardi, 2015) faydalanılmıştır.

Türkiye, Güney Kore, Hindistan, Mısır, Çin, Brezilya, Meksika, Endonezya ve Rusya gibi yükselen piyasa ekonomisi olarak tanımlanan ülkeler İspanyol bankacılık devi BBVA tarafindan 2010 yılında EAGLEs (Emerging and Growth Leading Economies- Yükselen ve Büyümenin Öncüsü Ekonomiler: Kartallar) olarak sınıflandırılmıştır. EAGLEs ülkeleri olarak nitelendirilen bu ülkelerin 2020 yılı itibariyle dünya ekonomik büyümesine $\% 60$ katk1 sağlayacağının öngörülmesiyle beraber bu katkının G7 ülkelerinin \%16'lık ortalama katkısından daha fazla olacağı belirtilmektedir (BBVA, 2012: 17). Yine ayrıca bu ülkelerin milli gelirlerinin 2014 ile 2024 yılları arasında G7 milli gelir ortalaması olarak tahmin edilen 475 milyar dolardan fazla olacağı ifade edilmektedir. Bununla beraber gelişmekte olan ülkelerin 2015-2025 döneminde küresel ekonomik büyümenin \%79'unu gerçekleştireceği ifade edilmekte ve bu büyüme oranının \%64'ünün EAGLEs ülkeleri tarafindan gerçekleştirileceği tahmininde bulunulmaktadır (BBVA, 2016: 5-6).

Tablo 1. Eagles Ülkeleri

\begin{tabular}{l} 
Brezilya \\
Çin \\
Endonezya \\
Güney Kore \\
Hindistan \\
Meksika \\
Misır \\
Rusya \\
Türkiye \\
\hline
\end{tabular}


Yaşam beklentisi, diğer bir deyişle doğuşta yaşam beklentisi çalışmada yer alan bağımlı değişken olup bireylerin beklenen yaşam süreleri kapsamında bilgi vermektedir. Özellikle sağlı alanındaönemli bir gösterge olup ülkelerdeki ortalama yaşam süresi ve sağlık hizmetlerinin gelişmişliği kapsamında fikir verebilmektedir. Bu değişkene dair verilere Dünya Bankası'nın veritabanındanulaşılmıştır.

KOF Küreselleşme Endeksi ise çalışmadaki bağımsız değişkeni ifade etmekte olup ülkelerin küreselleşme düzeylerini ifade eden bir göstergedir. KOF İsviçre Ekonomi Araştırmaları Enstitüsü tarafından yayınlanan bu endeks çerçevesindeülkeler, küreselleşme düzeylerine göre 0 ila 100 arası puanlanmaktadır. 100 en yüksek küreselleşme düzeyini, 0 ise en düşük küreselleşme seviyesini ifade etmektedir. Verilere KOF İsviçre Ekonomi Araştırmaları Enstitüsü veri tabanından ulaşılmıştır.

Bahsedilen bağımlı ve bağımsız değişken dışında çalışmaya ayrıca açıklayıcı değişkenler eklenmiştir. Satın alma gücü paritesine göre düzenlenmiş kişi başına düşen GSYIH, kentleşme oranı ve gayri safi sermaye oluşumu çalışmada yer alan açıklayıcı değişkenleri ifade etmektedir. Tüm bu açıklayıcı değişkenlere ait veriler Dünya Bankası'nın veritabanından elde edilmiştir.

Çalışma kapsamında tanımlanan hipotez aşağıdaki gibidir:

$H_{0}=$ Küreselleșmenin yaşam beklentisi üzerinde etkisi yoktur.

$H_{1}=$ Küreselleşmenin yaşam beklentisi üzerinde etkisi vardır.

Çalışmada ortaya konulan model aşağıdaki şekildedir:

$$
L E_{i t}=\alpha_{0}+\alpha_{1} G I_{i t}+\alpha_{2} G D P_{i t}+\alpha_{3} U P_{i t}+\alpha_{4} G C F_{i t}+\alpha_{i}+\lambda_{t}+\varepsilon_{i t}
$$

$L E_{i t}$ yaşam beklentisini, $G I_{i t}$ Küreselleşme Endeksini, $G D P_{i t}$ kişi başına düşen GSYİH'y1, $U P_{i t}$ kentleşme oranını, $G C F_{i t}$ gayrisafi sermaye oluşumunu, $\alpha_{0}$ sabit parametreyi, $\alpha_{i}$ birim etkiyi, $\lambda_{t}$ zaman etkisini ve $\varepsilon_{i t}$ ise hata terimini işaret etmektedir.

Çalışmada yer alan bağımlı ve bağımsız değişkenler, bu değişkenlere ait kısaltmalar ve bağımsız değişkenlerin bağımlı değişken üzerine beklenen etkileri Tablo 2'de görülmektedir.

Tablo 2. Değişkenler ve Beklenen Etkiler

\begin{tabular}{lll}
\hline Değişkenin Adı & $\begin{array}{l}\text { Değişkenin } \\
\text { Kısaltması }\end{array}$ & $\begin{array}{l}\text { Yaşam Beklentisi } \\
\text { Üzerine Etkiler }\end{array}$ \\
\hline $\begin{array}{l}\text { Küreselleşme } \\
\text { Endeksi }\end{array}$ & GI & + \\
$\begin{array}{l}\text { Kişi Başına Düşen } \\
\text { GSYİH }\end{array}$ & GDP & + \\
$\begin{array}{l}\text { Kentleşme Oranı } \\
\text { Gayrisafi Sermaye }\end{array}$ & GPF & + \\
Oluşumu & & + \\
\hline
\end{tabular}

Tablo 3'de ise çalışmada yer alan değişkenlere ait tanımlayıcı istatistikler yer almaktadır. Gözlem sayıları, ortalama değerler, standart sapmalar, her bir değişkene ait minimum ve maksimum değerler görülmektedir.

\begin{tabular}{llllll}
\hline Değişken & $\begin{array}{l}\text { Gözlem } \\
\text { Sayısı }\end{array}$ & Ortalama & $\begin{array}{l}\text { Standart } \\
\text { Sapma }\end{array}$ & Min. & Max. \\
\hline LE & 252 & 70.408 & 4.764 & 57.86 & 82.62 \\
GI & 252 & 59.716 & 9.420 & 32.14 & 79.34 \\
GDP & 252 & 10.772 & 7.653 & 0.987 & 38.82 \\
UP & 252 & 59.419 & 19.467 & 25.54 & 86.30 \\
GCF & 252 & 27.224 & 7.975 & 13.64 & 47.81 \\
\hline
\end{tabular}

\section{Ampirik Bulgular}

Çalışma kapsamında sırasıyla birimler arası korelasyon testi,birim kök testi, F testi, Hausman testi, değișen varyans ve otokorelasyon sınamaları gerçekleştirilmiştir. Nihai olarak ise uygun dirençli tahminci ile model tahmin edilmiştir.

Birimlere göre hata terimlerinin bağımsız olmasının panel veri modelleri kapsamında esas varsayımlardan birisi olduğu ifade edilmektedir. Fakat bu varsayımla uyuşmayacak şekilde bazı durumlarda yatay kesit veri birimler arasında hataların eşzamanlı olarak korelasyona sahip olduğu gözlemlenebilmektedir. Bundan dolayı birimler arası korelasyon sınaması önem arz etmektedir (Tatoğlu, 2016: 227).

Çalışma kapsamında birimler arası korelasyon sınaması için Pesaran Testi kullanılmıștır. Gerçekleştirilen Pesaran testinden elde edilen bulgular Tablo 4'de görülmektedir.

Tablo 4. Pesaran Testi

\begin{tabular}{ll}
\hline İstatistik Değeri & 1.688 \\
Olasılık Değeri & 0.0914 \\
\hline
\end{tabular}

Pesaran testi istatistik değeri 1.688 ve olasılık değeri 0.0914'tür. Birimler arası korelasyonsuzluğu temsil eden $H_{0}$ hipotezi kabul edilmiştir. Buna göre modelde birimler arası korelasyon problemine rastlanmamıştır.

Zaman serilerinde istatistiksel analizler yerine getirilmeden önce serinin durağan olup olmadığının araştırılması önem arz etmektedir. Çünkü durağan olmayan seriler dahil edilerek yapılan ekonometrik analizlerde sahte regresyon olarak nitelendirilen yanıltıcı ve sapmalı sonuçlarla karşılaş1labilmektedir. Bunun için ilk etapta serilerin durağanlığı incelenmelidir (Tatoğlu, 2013: 199).

Panel verilerin durağanlığını analiz etmek için çalışma kapsamında Fisher, Phillips ve Perron birim kök testi uygulanmıştır. Ulaşılan sonuçlar Tablo 5 'te görülmektedir.

Tablo 3. Tanımlayıcı İstatistikler

Tablo 5. Fisher,Phillips ve Perron Birim Kök Testi 


\begin{tabular}{llll}
\hline Değişkenler & $\begin{array}{l}\text { İstatistik } \\
\text { Değerleri }\end{array}$ & $\begin{array}{l}\text { Olasılık } \\
\text { Değerleri }\end{array}$ & Durağanlık \\
\hline LE & 94.9394 & 0.0000 & Düzey \\
GI & 86.9515 & 0.0000 & Düzey \\
GDP & 111.5896 & 0.0000 & 1. Fark \\
UP & 146.0367 & 0.0000 & Düzey \\
GCF & 33.0420 & 0.0165 & Düzey \\
\hline
\end{tabular}

Tablo 5'teki sonuçlar incelendiğinde GDP değişkeni dışındaki tüm değişkenlerin düzeyde durağan olduğu tespit edilmiştir. GDP değişkeninin ise birinci farkında durağan olduğu gözlemlenmektedir.

Modelin tahmin edilmeden önceki aşamalardan bir diğeri birim ve zaman etkilerinin varlığının araştırılmasıdır. Birim ve/veya zaman etkileri bulunmuyor ise klasik model geçerli olacaktır. Birim ve zaman etkilerinin varlığını sınamak için F testi kullanılmaktadır.

Tablo 6. F Testi

\begin{tabular}{ll}
\hline F İstatistiği & 107.45 \\
Olasılık Değeri & 0.0000
\end{tabular}

Tablo 6'da F testine dair bulgular görülmektedir. Buna göre klasik model reddedilmiştir. Olasılık değeri birim veya zaman etkilerinin bulunduğunu ifade etmektedir. Klasik model etkin değildir.

Hausman spesifikasyon testi sabit etkili ve tesadüfi modeller arasında tercih yapmaya yarayan bir etkinlik analiz aracı olarak ifade edilmektedir. Modelin sabit etkiler tahmincisi ve tesadüfi etkiler tahmincisinden hangisi ile tahmin edileceğinin belirlenmesi için ilk olarak Hausman testi gerçekleştirilmelidir.

Tablo 7. Hausman Testi

\begin{tabular}{ll}
\hline Ki-kare İstatistiği & 1.05 \\
Olasılık Değeri & 0.9026 \\
\hline
\end{tabular}

Tablo 7'de Hausman Testine dair bulgular yer almaktadır. Ki kare istatistik değeri ve olasılık değerlerinin yer aldığı bulgular değerlendirildiğinde tesadüfi etkiler modelinin sabit etkiler modeline göre etkin olduğu bulgusuna ulaşılmıştır.

Varyansın birimlere göre değişmesi, değişen varyans olarak ifade edilmekte olup istatistiki analizlerde karşılaşılmak istenmeyen bir durumu göstermektedir. Özellikle yatay kesit verilerle ve yatay kesit veriler ile zaman serisi verilerin bileşimi olan panel veri çalışmalarından sıklıkla rastlanılan değişen varyans problemi göz ardı edilerek analiz gerçekleştirildiğinde yanıltıcı istatistiki bulgular elde edilebilmektedir.

Çalışmada değişen varyans problemini test etmek için Levene, Brown ve Forsythe testi uygulanmıştır. Tesadüfi etkiler tahmincisinin etkin olduğu modellerde uygulanabilen Levene BrownveForsythe testine dair bulgular Tablo 8'de görülmektedir.
Tablo 8. Levene, Brown ve Forsythe Testi

\begin{tabular}{ll}
\hline$H_{0}=$ Değişen varyans yoktur & \\
\hline Test İstatistiği & Prob>F \\
\hline $\mathrm{W} 0=6.4714937$ & 0.00000012 \\
$\mathrm{~W} 50=3.9129780$ & 0.00022944 \\
$\mathrm{~W} 10=5.9460542$ & 0.00000058 \\
\hline
\end{tabular}

Levene, Brown ve Forsythe testine dair bulgular $H_{0}$ hipotezinin reddedildiğini göstermektedir. Tahmin edilen modelde değişen varyans problemine rastlanmıştır.

Değişen varyans probleminin dışında bir diğer istatistiksel sorun otokorelasyon bulgusudur. Hata terimlerinin birbirleri ile ilişkili olma durumu otokorelasyon olarak adlandırılmaktadır. İstatistiki analizler gerçekleştirilmeden önce modelde otokorelasyonun varlığı sınanmalıdır.

Otokorelasyon sınamasını gerçekleştirebilmek için çalışmada Bhargava, Franzini ve Narendranathan'ın DurbinWatson ve Baltagi-Wu'nun Yerel En İyi Değişmez testleri gerçekleştirilmiştir. Söz konusu testler tesadüfi etkili modellerde uygulanabilmektedir.

Tablo 9. Bhargava, Franzini ve Narendranathan'in Durbin-Watson Testi ve Baltagi-Wu Testi

Bhargava, Franzini ve Narendranathan'ın 0.16444203
Durbin-Watson Test İstatistik Değeri

Baltagi-Wu Test İstatistik Değeri

0.47877362

Tablo 9'da Bhargava, Franzini ve Narendranathan'ın Durbin-Watson ve Baltagi-Wu'nun Yerel En İyi Değişmez testine dair ulaşılan bulgular görülmektedir. Ulaşılan her iki test istatistik değerinin de 2'den oldukça küçük olduğu gözlemlenmektedir. Ulaşılan bu bulgular model kapsamında otokorelasyon probleminin var olduğunu ifade etmektedir.

\section{Tahmin Sonuçları}

Çalışma kapsamında belirtilen amaca ulaşmak için ilk olarak değişkenlerin durağanlıkları Fisher Phillips ve Perron birim kök testi ile sınanmış, daha sonra ise klasik modelin varlığ F testi ile araştırılmıştır. Klasik modelin etkin olmadığ bulgusuna ulaşıldıktan sonra sabit etkiler ve tesadüfi etkiler modeli arasında Hausman etkinlik testi gerçekleştirilmiştir. Hausman testi sonucunda tesadüfi etkiler modelinin etkin olduğu gözlemlenmiştir. Değişen varyans sinaması ise Levene Brown ve Forsyhe testi ile gerçekleştirilmiş ve değişen varyans problemine rastlanmıştır. Son olarak Bhargava, Franzini ve Narendranathan'in Durbin-Watson test istatistiği ve Baltagi-Wu test istatistiği modelde otokorelasyonprobleminin olduğunu göstermiştir.

Tüm bu testler gerçekleştirildikten sonraki aşama modelin uygun dirençli tahminci ile tahmin edilmesidir. Çalışmada modelin tahmin edilebilmesi için Arellano, Froot ve Rogers dirençli tahmincisi kullanılmıştır. Arellano, Froot ve Rogers dirençli tahmincisi hem sabit etkiler modelinin etkin oldığu durumlarda hem de tesadüfi etkiler modelinin etkin olduğu 
durumlarda uygulanabilmektedir. Arellano, Froot ve Rogers tahmincisi ile dirençli standart hatalar türetilebilmektedir.

Tablo 10. Tahmin Sonuçları

\begin{tabular}{llll}
\hline $\begin{array}{l}\text { Bağımsız } \\
\text { Değişkenler }\end{array}$ & Katsayı & $\begin{array}{l}\text { Dirençli } \\
\text { Standart } \\
\text { Hatalar }\end{array}$ & $\begin{array}{l}\text { Olasılık } \\
\text { Değeri }\end{array}$ \\
\hline GI & 0.2235009 & 0.0510296 & $0.000^{* * * *}$ \\
GDP & 0.0984016 & 0.0483832 & $0.042^{* *}$ \\
UP & 0.1086621 & 0.0802563 & 0.176 \\
GCF & 0.0494371 & 0.0514401 & 0.337 \\
\hline
\end{tabular}

$R^{2}=0.6320$

$$
\begin{aligned}
& \text { ***: \%1 Anlamlılık Düzeyi } \\
& \text { **: \%5 Anlamlılık Düzeyi } \\
& \text { *: \%10 Anlamlılık Düzeyi }
\end{aligned}
$$

Tablo 10'da Arellano, Froot ve Rogers dirençli tahmincisine ait bulgular yer almaktadır. $R^{2}$ değeri 0.6320 olup bu değer aynı zamanda bağımsız değişkenlerin bağımlı değişkeni açıklama gücünü ifade etmektedir.

GI değişkeninin katsayısı incelendiğinde katsayının yönünün beklenildiği gibi pozitif ve istatistiksel olarak \%1 önem düzeyinde anlamlı olduğu gözlemlenmektedir. Eagles ülkelerinde küreselleşme düzeyi yükseldikçe yaşam beklentisi artmaktadir.

GDP değişkeni ile LE değişkeni arasındaki ilişki analiz edildiğinde katsayının yönünün pozitif olduğu görülmektedir. Ulaşılan sonuç aynı zamanda istatistiksel olarak \%5 önem düzeyinde anlamlıdır. Eagles ülkelerinde kişi başına düşen GSYİH arttıkça yaşam beklentisi yükselmektedir.

UP değişkeninin katsayısına bakıldığında katsayının yönünün pozitif olduğu tespit edilmiştir. Fakat ulaşılan sonuç istatistiksel olarak anlamsızdır.

GCF değişkeni ile LE değişkeni arasındaki ilişki incelendiğinde katsayının yönünün beklenilen bulgularla uyumlu olmak üzere pozitif olduğu görülmektedir. Fakat elde edilen sonuç istatiksel olarak anlamsızdır.

\section{Sonuç}

Küreselleşme, ekonomilerin, ulusların birbirine entegre olmasını ifade etmektedir. Modern dünya ülkelerinin serbest ekonomi anlayışına sahip olmaları küreselleşmenin yayılmasını sağlamış, ticari faaliyetlerde liberalizasyona yol açmıştır. Küreselleşme daha çok ekonomik bir faktör olarak nitelendirilse de sosyal ve kültürel boyutları da bulunmaktadir.

Küreselleşmenin beşeri sermaye üzerine de etkili olduğu ifade edilmektedir. Eğitim ve sağlık gibi beşeri sermaye unsurları da küreselleşmeden etkilenebilmektedir. Küreselleşme ile sağlık göstergeleri arasındaki ilişki analiz edildiğinde bu ilişkinin yönü kapsamında tartışmalar süregelmektedir. Küreselleşmenin sağlık hizmetleri içerisinde özellikle modern tıbbi imkanların kullanılmasına olanak tanıması gibi önemli bir avantajı bulunmakta iken küreselleşmeyle beraber hastalıkların başka toplumlara nüfuz edebilmesi gibi birtakım dezavantajları da bulunabilmektedir.

Küreselleşmenin bir sağlık göstergesi olarak doğuşta yaşam beklentisi üzerine olan etkilerini doğrudan araştıran çalışma sayısı az olmakla beraber mevcut çalışmalarda ulaşılan sonuçlar genellikle küreselleşmenin yaşam beklentisini olumlu yönde etkilediği yönündedir (Berhg ve Nilsson, 2011; Ali ve Audi, 2016; Timothy, 2018).

Çalışmada küreselleşmenin yaşam beklentisi üzerindeki etkileriEagles Ülkeleri kapsamında araştırılmıştır. Ulaşılan sonuçlar Eagles ülkelerinde küreselleşmenin yaşam beklentisini artırdığını göstermektedir. Aynı zamanda Eagles ülkelerinde kişi başına düşen GSYİH yaşam beklentisini artırmaktadır.Ulaşılan bulgular literatürdeki benzer çalışmalarda elde edilen sonuçlarla uyum içerisindedir (Berhg ve Nilsson, 2011; Ali ve Audi, 2016; Timothy, 2018).

Ulaşılan bulgulardan yola çıkarak özellikle küreselleşmenin daha iyi sağlık hizmeti verilebilmesine yönelik tıbbi araç ve gereçlerin diğer ülkelerden transfer edilebilmesiyle ülkelere ve toplumlara fayda sağlayabileceği ifade edilebilir. Yine bireylerin sihhat bulmalarına imkan tanıyan ve ülke içerisinde üretilmeyen ilaçlar küreselleşmenin de etkisi ile beraber başka ülkelerden ithal edilebilir. Küreselleşme gıda güvenliğine katkı sağlar ve dolaylı olarak bireylerin doğuşta yaşam beklentilerini artırabilir. Küreselleşme bilginin maliyetini azaltarak daha hızlı yayılmasını sağlar ve böylelikle insanlar bulaşıcı hastalıklara yönelik daha kısa sürede bilinçli bireylere dönüşebilirler.

\section{Kaynakça}

Ali. A. \& Audi, A. (2016). The Impact of Income Inequality, Environmental Degradation and Globalization on Life Expectancy in Pakistan: An Empirical Analysis, International Journal of Economics and Empirical Research, 4(4), 182-193.

BBVA (2012). EAGLEs Annual Report,https://www.bbvaresearch.com/en/publicacio nes/bbva-eagles-annual-report-2012/ (Erişim Tarihi: 02.03.2020).

BBVA (2016). EAGLEs Economic Outlook Annual Report, https://www.bbvaresearch.com/en/publicaciones/eag les-economic-outlook-annual-report-2016/ (Erişim Tarihi: 02.03.2020).

Bergh, A. \& Nilsson, T. (2010). Good for Living? On the Relationship between Globalization and Life Expectancy, World Development, 38(9), 1191-1203.

Bezruchka, S. (2000). Is Globalization Dangerous to Our Health?, West J Med., 172 :332-334.

Cornia, G. A. (2001). Globalization and Health: Results and Options,Bulletin of the World Health Organization, 79, 834-841.

Deaton, A. (2004). Health in an Age of Globalization, Brookings Trade Forum 2004. Washington, D.C.: Brookings Institution Press, pp, 83-130. 
Diaz-Bonilla E., Babinard J., Pinstrup-Andersen P. \& Thomas, M. (2002). Globalizing Health Benefits For Developing Countries. Workshop Interfaces of Developing Countries' Strategies with Global Governance. Conflicts and Cooperation in the Health Sector, Hamburg, Germany. Available at: http://www.ifpri.org/divs/tmd/dp/tmdp108.htm (Erişim Tarihi: 22.12.2019).

Ertaş, H. \& Çiftçi Kıraç, F. (2017). Küreselleşmelerin Ülkelerin Sağlık Sistemleri ve Politikaları Üzerine Etkileri, Kastamonu Üniversitesi İktisadi ve İdari Bilimler Fakültesi Dergisi, 17(3), ss. 28-34.

Fischer, S. (2003). Globalization and Its Challenges, American Economic Review, 93(2), 1-30.

Labonte R, Mohindra K \& Schrecker T. (2011). The Growing Impact of Globalization on Health and Public Health Practice, Annu Rev Public Health, 32, 263-283.

Lee, E. \& Vivarelli, M. (2006). The Social Impact of Globalization in the Developing Countries, IZA Discussion Paper, No. 1925, January 2006.

Monsef, A. \& Mehrjardi, A.S. (2015). Determinants of Life Expectancy: A Panel Data Approach, Asian Econ. Financ. Rev., 5, 1251-1257.

Preston, S. H. (1975). The Changing Relation Between Mortality and Level of Economic Development, Population Studies, 29, 231-248.

Prichett, L. \& Summers, L. H. (1996). Wealthier is Healthier, Journal of Human Resources, 31(4), 841-868.
Rabbi, A. M. F. (2013). Imbalance in Life Table: Effect of Infant Mortality on Lower Life Expectancy at Birth, Journal of Scientific Research, 5(3), 479-488.

Rafat, B., Emadzadeh, M., \& Ahmadi, K. (2013). Economic, Social and Political Aspect of Globalization on Health in Developing Countries (with Segregation). International Journal of Academic Research in Business \& Social Sciences, 3(7), 384-402.

Stallings, B. (2002). Globalization and Liberalization: The Impact on Developing Countries. In States, Markets and Just Growth: Development in the 21st Century, ed. Atul Kohli, Chung-In Mon and George Sorensen. Tokyo: United Nations Press.

Timothy, P. O. (2018). Impact of Economic Globalization on Life Expectancy in Nigeria, Health Economics \& Outcome Research: Open Access, 4(2), 152.

Welander, A., Lyttkens, C. H. \& Nilsson, T. (2015). Globalization, Democracy and Child Health in Developing Countries, Social Science \& Medicine, Volumes 136-137, pp 52-63.

Whalley, J. (2005). Globalization and Values, CESifo Working Paper Series, No. 1441, April 2005.

Tatoğlu, F. Y. (2013). İleri Panel Veri Analizi, Beta Yayıncılık, İstanbul.

Tatoğlu, F. Y. (2016). Panel Veri Ekonometrisi Stata Uygulamalı, Beta Yayıncılık, İstanbul. 